\section{A case of curiosities}

\section{Richard Davenport-Hines}

Henry Wellcome. By Robert Rhodes James. Hodder and Stoughton: 1994. Pp. 422. £25.

THE old-fashioned phrase 'a man of parts' might have been coined to describe Henry Wellcome (1853-1936), pharmaceutical multimillionaire, collector and philanthropist. The son of a farmer and fanatical itinerant preacher, he was born in a frontier settlement in Wisconsin and educated in a log-cabin school in Minnesota and at the Chicago School of Pharmacy. From an early age (perhaps as a reaction to the dyslexia and religious bigotry that ran in his family) he evinced "hero-worship of better minds than his own, and ... fascination with ideas and intellect". As a salesman he travelled all over the Americas in the 1870 s, peddling medicines with furious energy as a way to escape from boyhood poverty. In 1880 he became the junior partner of an Englishman, Silas Burroughs, specializing in a line of products with the tradename Tabloids. Their relationship later became very strained, but attempts to dislodge Wellcome from the business failed, and he took control of the company on the death of Burroughs in 1895.

Over the next two decades, Wellcome proved himself to be a keen, resourceful and flexible businessman who pushed the Burroughs Wellcome company to the forefront of the British pharmaceutical sector. His greatest contribution to British pharmaceutical history was to set up the semi-independent Wellcome Physiological

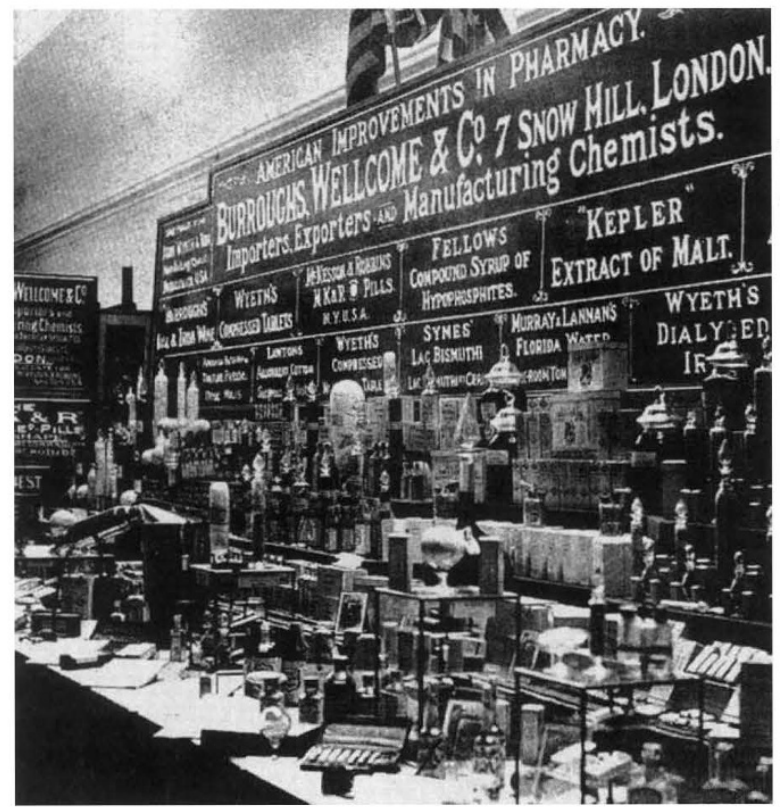

A medical and sanitary exhibition, London, 1881.
Research Laboratories with the highest standards of research and quality control. The researches of pharmacists had hitherto been tainted as dishonest quackery, but it was Wellcome's achievement to remove suspicion of 'commercialization' from scientific work. He also expanded the overseas operations of the company, which after 1914 made a crucial contribution to sera and vaccines needed during the war.

Comparison with the other great pioneering leader of British pharmaceutical enterprise, Sir Harry Jephcott of Glaxo, is instructive. Jephcott was originally a research scientist who worked his way up in a company owned by others. He had all the qualities of a company insider. He was discreet, modest, unneurotic, leading his employees by example rather than intimidation, and was understandably adored by many of them. Wellcome the founding entrepreneur was neurotic, turbulent, flamboyant, self-centred and often destructive in his effects, although his instincts were generous; he had few friends, and was respected rather than admired. Both men had exceptional tenacity, energy and a powerful instinct for research strategies and their commercial possibilities.

As well as being an innovative entrepreneur, Wellcome had a mania for collecting curios, a passion that contributed to the failure of his marriage to Syrie Barnardo, daughter of the medical philanthropist who founded the Barnardo Homes for orphans. He amassed a huge collection of objects intended for the Wellcome Historical Medical Museum which he founded in 1913. His collection was very idiosyncratic: after his death it was found to include items as disparate as a rose from the garden at Khartoum of General Gordon, the wheelbarrow, cord and trapeze with which Blondin crossed the Niagara Falls, more than 80,000 models of patents registered in the US Patent Office that had never been uncrated, 17,000 amulets, 52 cases of flints and 4,000 spears. His historical collections were not intended for the general public ("stragglers", as he called them); rather, they were intended to serve as a laboratory where cultural and technological problems would be solved, an activity

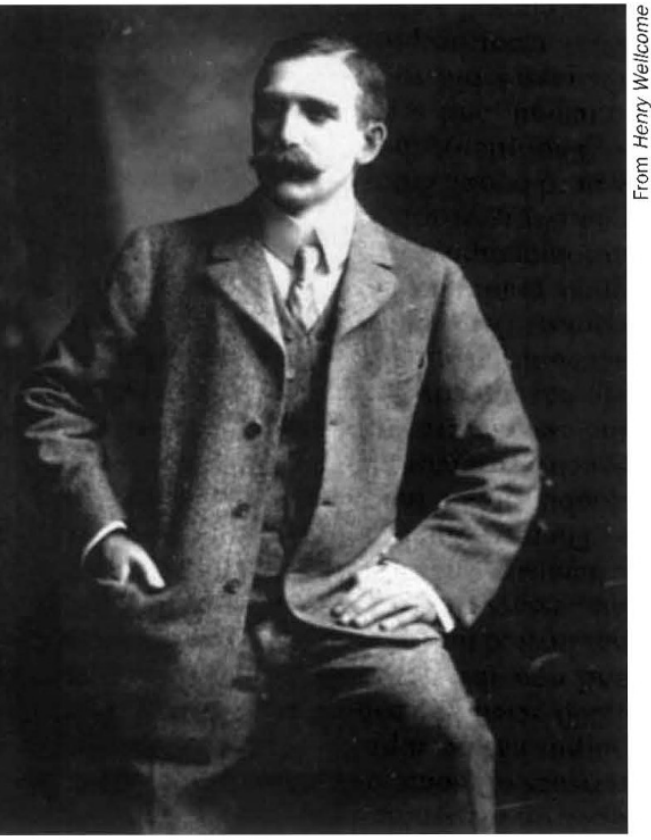

nry Wellcome in 1902.

to which he devoted increasing amounts of time to the detriment of his day-to-day business operations.

In 1924 Wellcome consolidated his separate enterprises - nine companies, his research laboratories and museum - in one private company, the Wellcome Foundation, control of which he bequeathed to trustees. Under the terms of his will he subdivided his empire into the Wellcome Foundation, operating its pharmaceutical business, and the Wellcome Research Institution, funded by the former's profits and pursuing a range of chemical, physiological, entomological, archaeological and historical research. Thus, confusingly, the Wellcome Trust (established by his will) became the real 'foundation' charged with distributing the income from Wellcome shares - the Wellcome Foundation acts as the commercial arm. He also tried to impose complex and sometimes inoperable instructions on his managers from beyond the grave. His instructions to his trustees were absurdly grandiose and led to decades of legal wrangling.

Sir Robert Rhodes James, a retired member of the British parliament, has written an elegant, readable and meticulously researched biography of this sad tycoon. Rhodes James is never sycophantic and does not flinch from showing his subject's arrogance or dismal old age, but the overall mood of his book is generous and broad-minded. He touches on issues such as the commercialization of science and charitable administration, but above all gives a vivid study of practical idealism and of the megalomania that develops from the isolation of great riches. 